\title{
KEMAMPUAN CALON GURU (PRE-SERVICE TEACHER) BIOLOGI MERENCANAKAN PEMBELAJARAN BERBASIS KETERAMPILAN PROSES SAINS (SCIENCE PROCESS SKILLS)
}

\author{
Listika Yusi Risnani \\ Uni versitas Muhammmadi yah Purwokerto \\ E-mail: listikayusi@yahoo.co.id
}

\begin{abstract}
This study aims to determine the ability of biology teacher candidate (pre-service teacher) in planning science process skills (SPS) based learning. This research was descriptive evaluative approach with document analysis. The population is student of semester VI as pre-service teacher at Biology Education Program of Muhammadiyah University of Purwokerto. The subjects consisted of 18 students divided into two classes. The instruments of data collection used are documents are lesson plan, questionnaire and observation sheet. Data analysis techniques used are quantitative and qualitative data analysis techniques. The results show that the ability of pre-service biology teachers in preparing the learning objectives of $28-50 \%$, the preparation of SPS materials is $0 \%$, the ability to prepare leaming steps on basic skills (11-89\%), process skills (7-78\%) and integrative skills (7-93\%), and the ability to prepare a assessment of SPS (11.11\%). The conclusion of this research is the ability of pre-service biology teacher in planning science process skills (SPS) based learning is still low so that efforts are needed to improve with the improvement of learning held in Biology Education.
\end{abstract}

Kata kunci : calon guru biologi, pe mbelajaran, keterampilan proses sains

cabang iogi sebagai salah satu pengalaman belajar peserta didik untuk memahami konsep dan proses sains sehingga domain proses idealnya dikembangkan dan menjadi tujuan penting pada proses pembelajaran biologi (Harlent, 2001). Hal tersebut diperkuat oleh adanya standar kompetensi lulusan mata pelajaran Biologi SMA/MA yaitu penguasaan sejumlah keterampilan proses yang mencakup merumuskan masalah, mengajukan dan menguji hipotesis, menentukan variabel, merancang dan merakit instrumen, menggunakan berbagai peralatan untuk keperluan pengamatan dan pengukuran yang tepat dan teliti, mengumpulkan, mengolah, menafsirkan dan menyajikan data secara sistematis, dan menarik kesimpulan, serta berkomunikasi ilmiah terkait hasil percobaan secara lisan dan tertulis (Kemdiknas, 2006: 369). Berdasarkan hal tersebut, belajar biologi erat kaitannya dengan belajar metode ilmiah (scientific method) dengan melibatkan sejumlah keterampilan proses sains (KPS).

Pembelajaran biologi di SMA/MA idealnya dilaksanakan melalui pembelajaran dengan melatihkan dan mengembangkan KPS kepada peserta didik. KPS sebagai proses mental dan perilaku fisik yang digunakan dalam memperoleh, memahami, dan melakukan interpretasi terhadap data untuk menerima, memperoleh dan mengembangkan ilmu sains (Aktamis \& Ergin, 2008; Harlent, 
2001). Ilmuwan menggunakan sejumlah KPS untuk menghasilkan informasi ilmiah, penelitian ilmiah dalam rangka untuk memecahkan masalah. Diharapkan dengan penguasaan KPS yang memadai untuk memahami sains murni (nature science), peserta didik dapat melakukan setiap langkah dalam kehidupannya secara ilmiah untuk meningkatkan kualitas dan standar kehidupannya kelak.

KPS dalam mata pelajaran biologi SMA dilaksanakan melalui kegiatan mengamati, mengajukan hipotesis, menggunakan alat dan bahan dengan baik dan benar dengan selalu mempertimbangkan keamanan dan keselamatan kerja, mengajukan pertanyaan, menggolongkan dan menafsirkan data, serta mengkomunikasikan hasil temuan secara lisan dan tertulis, menggali dan memilih informasi faktual yang relevan untuk menguji gagasan atau untuk memecahkan masalah sehari-hari (BNSP, 2006: 167). Menurut Bryce et al. (1990) KPS dibagi menjadi keterampilan dasar (basic skills), keterampilan mengolah atau memproses (process skills) dan keterampilan melakukan investigasi (investigative skills). Keterampilan dasar mencakup: 1) keterampilan melakukan pengamatan,

keterampilan merekam data, 3) keterampilan melakukan pengukuran, 4) keterampilan melakukan manipulasi, 5) keterampilan mengimplementasikan prosedur, dan 6) keterampilan mengikuti intruksi. Keterampilan mengolah atau memproses mencakup : 1) keterampilan menginferensi, dan 2) kemampuan menyeleksi berbagai cara atau prosedur. Keterampilan investigasi mencakup: merencanakan 1) kemampuan kemampuan melaksanakan investigasi, dan 3) kemampuan melaporkan hasil investigasi.

KPS pada penelitian ini menggabungkan KPS menurut BNSP (2006) dan menurut Bryce et al. (1990) yaitu meliputi keterampilan dasar, keterampilan proses atau mengolah, dan keterampilan melakukan investigasi.

Tabel 1. Aspek keterampilan proses Sains

\begin{tabular}{|c|c|c|}
\hline No & $\begin{array}{l}\text { Tingkatan } \\
\text { KPS }\end{array}$ & Aspek KPS \\
\hline \multirow{7}{*}{1} & \multirow{7}{*}{$\begin{array}{l}\text { Basic } \\
\text { skills }\end{array}$} & $\begin{array}{ll}\text { a. } & \begin{array}{l}\text { Ketera mpilan } \\
\text { menga mati }\end{array} \\
\end{array}$ \\
\hline & & $\begin{array}{l}\text { b. Keterampilan } \\
\text { merekam data/ } \\
\text { informasi }\end{array}$ \\
\hline & & $\begin{array}{l}\text { c. Keterampilan } \\
\text { mengikuti } \\
\text { instruksi }\end{array}$ \\
\hline & & $\begin{array}{ll}\text { d. } & \text { Ketera mpilan } \\
& \text { mengklasifikasi } \\
\end{array}$ \\
\hline & & $\begin{array}{ll}\text { e. } & \begin{array}{l}\text { Keterampilan } \\
\text { me lakukan } \\
\text { pengukuran }\end{array} \\
\end{array}$ \\
\hline & & $\begin{array}{ll}\text { f. } & \text { Keterampilan } \\
\text { melakukan } \\
\text { manipulasi } \\
\text { gerakan, }\end{array}$ \\
\hline & & $\begin{array}{ll}\text { g. Ke mampuan } \\
\text { mengimple menta } \\
\text { sikan prosedur/ } \\
\text { teknik/ } \\
\text { penggunaan } \\
\text { peralatan } \\
\end{array}$ \\
\hline \multirow{3}{*}{2} & \multirow{3}{*}{$\begin{array}{l}\text { Process } \\
\text { skills }\end{array}$} & $\begin{array}{ll}\text { a. } & \begin{array}{l}\text { Keterampilan } \\
\text { membuat } \\
\text { prediksi }\end{array} \\
\end{array}$ \\
\hline & & $\begin{array}{ll}\text { b. } & \begin{array}{l}\text { Keterampilan } \\
\text { membuat } \\
\text { inferensi }\end{array} \\
\end{array}$ \\
\hline & & 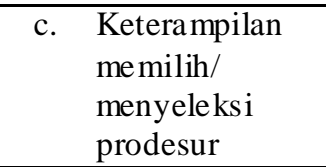 \\
\hline 3 & $\begin{array}{l}\text { Investigati } \\
\text { ve skills }\end{array}$ & $\begin{array}{ll}\text { a. } & \begin{array}{l}\text { Keterampilan } \\
\text { merancang } \\
\text { investigasi }\end{array} \\
\end{array}$ \\
\hline
\end{tabular}




\begin{tabular}{|c|c|c|}
\hline & & $\begin{array}{ll}\text { b. } & \text { Ketera mpilan } \\
\text { melaks anakan } \\
\text { investigasi }\end{array}$ \\
\hline & & $\begin{array}{l}\text { c. Ketera mpila } \\
\mathrm{n} \text { melaporkan } \\
\text { hasil investigasi }\end{array}$ \\
\hline
\end{tabular}

Program Studi Pendidikan Biologi sebagai bagian dari FKIP Universitas Muhammadiyah Purwokerto (UMP) merupakan salah satu Lembaga Pendidikan Tenaga Kependidikan (LPTK) yang mencetak calon guru/tenaga kependidikan profesional. Salah satu profil lulusan dari Program Studi Pendidikan Biologi adalah menjadi calon guru atau tenaga kependidikan biologi yang profesional. Guru yang professional berkaitan dengan keprofesionalan baik ketika menjalani pendidikan (preservice teacher) dan keprofesionalan selama menjalani profesinya sebagai guru (inservice teacher). Calon guru biologi dipersiapkan menjadi guru professional salah satunya pada pembelajaran mata kuliah microteaching. Pada mata kuliah microteaching mahasiswa dituntut untuk praktek mengajar pada skala mikro di kelas termasuk membuat rancangan pembelajaran yang meliputi penyusunan rencana pelaksanaan pembelajaran (RPP), penyiapan media dan sumber belajar, perangkat penilaian pembelajaran dan skenario pembelajaran.

Setiap pendidik pada satuan pendidikan berkewajiban menyusun RPP secara lengkap dan sistematis agar pembelajaran berlangsung secara interaktif, inspiratif, menyenangkan, menantang, efisien, memotivasi peserta didik untuk berpartisipasi aktif (Kemendikbud, 2013: 6). Pembelajaran biologi yang dirancang dalam bentuk RPP oleh calon guru atau tenaga kependidikan idealnya didasarkan pada pemahaman biologi sebagai bagian dari sains sehingga merencanakan pembelajaran biologi harus memperhatikan hakekat sains yang melibatkan sejumlah KPS. KPS dapat dilatihkan dan dikembangkan dengan oleh guru dengan menggunakan berbagai pendekatan, strategi dan model pembelajaran yang disesuikan dengan kompetensi dasar yang akan dicapai (Kemendikbud, 2013). Pembelajaran biologi dengan mengembangkan KPS dilaksanakan berbasis penemuan (inquiry) yang berpusat pada siswa (student center learning). Peserta didik aktif terlibat dalam proses inkuiri, sementara guru membimbing untuk mencapai pemahaman yang bermakna tentang ide yang diterima secara ilmiah. Menurut National Science Education Standart (Schwartz et al., 2004 ), peserta didik yang dilatih KPS akan memiliki literasi sains yaitu kemampuan untuk menggunakan prinsip sains dan proses sains tersebut untuk membuat keputusan pribadi dan dapat berpartisipasi aktif pada diskusi perihal isu sains yang muncul di masyarakat.

Penelitian ini akan mengkaji tentang kemampuan calon guru biologi dalam merancang pembelajaran berbasis KPS. Hasil penelitian ini akan memberikan gambaran yang dibutuhkan untuk proses perbaikan dan pengembangan pembelajaran pada Program Studi Pendidikan Biologi sebagai lembaga yang bertanggungjawab mencetak calon guru biologi yang professional.

\section{METODE}

Penelitian ini dilaksanakan dengan menggunakan pendekatan deskriptif evaluatif dengan analisis 
dokumen. Populasi penelitian adalah seluruh mahasiswa semester VI pada Program Studi Pendidikan Biologi Universitas Muhammadiyah Purwokerto pada mata kuliah microteaching pada tahun ajaran 2015/2016. Sampel penelitian menggunakan sebanyak 18 mahasiswa yang terbagi dalam dua kelas yang masing-masing kelas terdiri dari 9 mahasiswa. Kelas sampel dipilih dengan menggunakan teknik cluster random sampling yaitu sebanyak $50 \%$ dari jumlah populasi. Setiap mahasiswa akan diamati kemampuannya menyusun rencana pembelajaran berbasis KPS pada 3 RPP yaitu RPP kelas X, RPP kelas XI dan RPP kelas XII.

Teknik pengumpulan data dilakukan dengan cara observasi dan non tes. Observasi dilakukan terhadap RPP dirancang oleh calon guru biologi untuk mengetahui kemampuan merencanakan pembelajaran biologi berbasis KPS. Sebanyak 54 RPP kelas X, XI dan XII diteliti sesuai dengan kriteria dan indikator dari pembelajaran berbasis KPS. Teknik non tes dilakukan dengan menggunakan angket dan lembar observasi sebagai data pendukung hasil temuan. Angket yang digunakan telah diuji validitas dan reliabilitasnya sehingga layak untuk digunakan untuk menghimpun data. Teknik analisis data yang dilakukan dalam penelitian ini adalah analisis deskriptif kuantitatif dan deskrip tif kualitatif.

\section{HASIL}

\section{Kemampuan Merumuskan Tujuan Pembelajaran}

Tujuan pembelajaran yang dirancang oleh calon guru diteliti berdasarkan kelengkapan cakupan, kesesuaian dengan kompetensi dasar dan kesesuaiannya dengan pembelajaran berbasis KPS. Sebagian besar calon guru $(89 \%)$ telah mampu merumuskan tujuan pembelajaran yang lengkap dilihat dari berbagai unsur yaitu unsure $\mathrm{A}$ (audiens), B (behavior), $\mathrm{C}$ (condition) dan D (degree). Tujuan pembelajaran yang dirumuskan calon guru (100\%) juga sudah sesuai dengan kompetensi dasar yang hendak dicapai dalam pembelajaran. Hasil penelitian menunjukkan bahwa calon guru sudah merumuskan tujuan pembelajaran berbasis KPS. Terdapat sebanyak $28 \%$ calon guru sudah merumuskan tujuan pembelajaran keterampilan dasar (basic skills), 50 $\%$ mahasiswa merumuskan tujuan pembelajaran untuk aspek keterampilan menginvestigasi (investigative skills) dan belum ada $(0 \%)$ calon guru yang merumuskan tujuan pembelajaran pada keterampilan memproses (process skills; Gambar 1). 


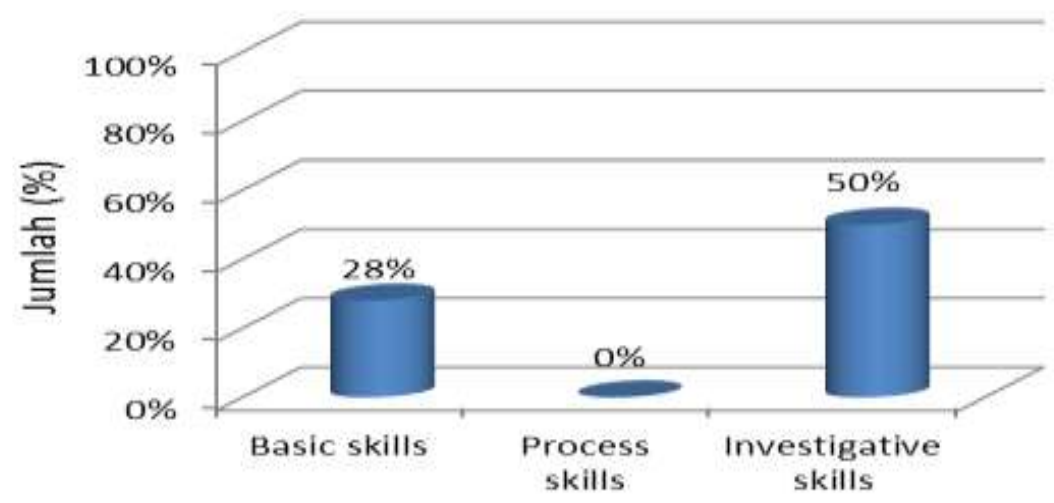

Keterampilan Proses Sains

Gambar 1. Kemampuan merumuskan tujuan pembelajaran berbasis KPS

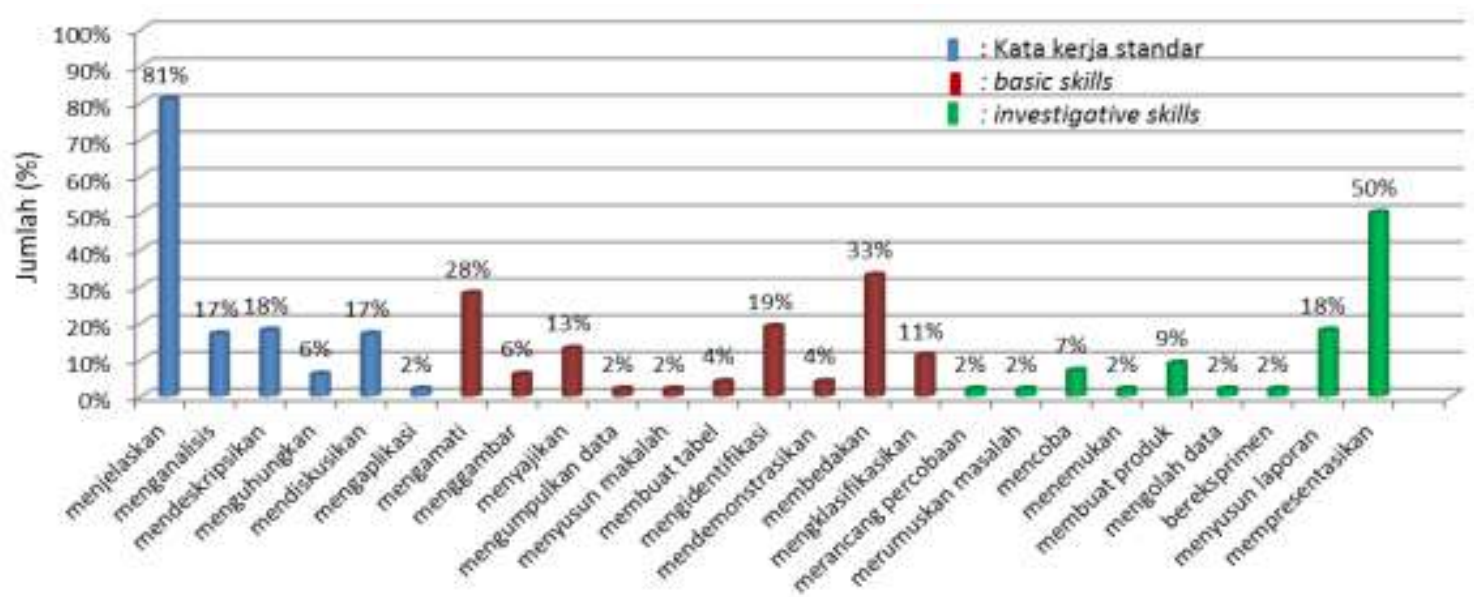

Kata Kerja Operasional

Gambar 2. Kata kerja operasional yang disusun oleh calon guru

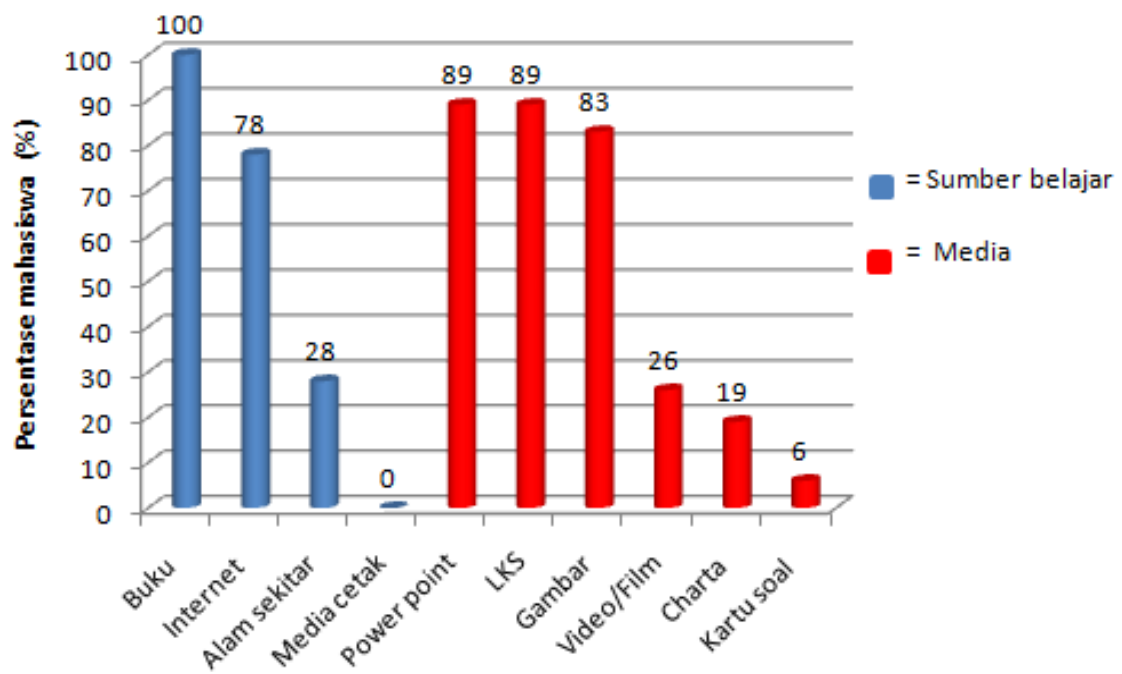

Gambar 3. Sumber dan media pembelajaran yang dirumuskan oleh calon guru biologi 


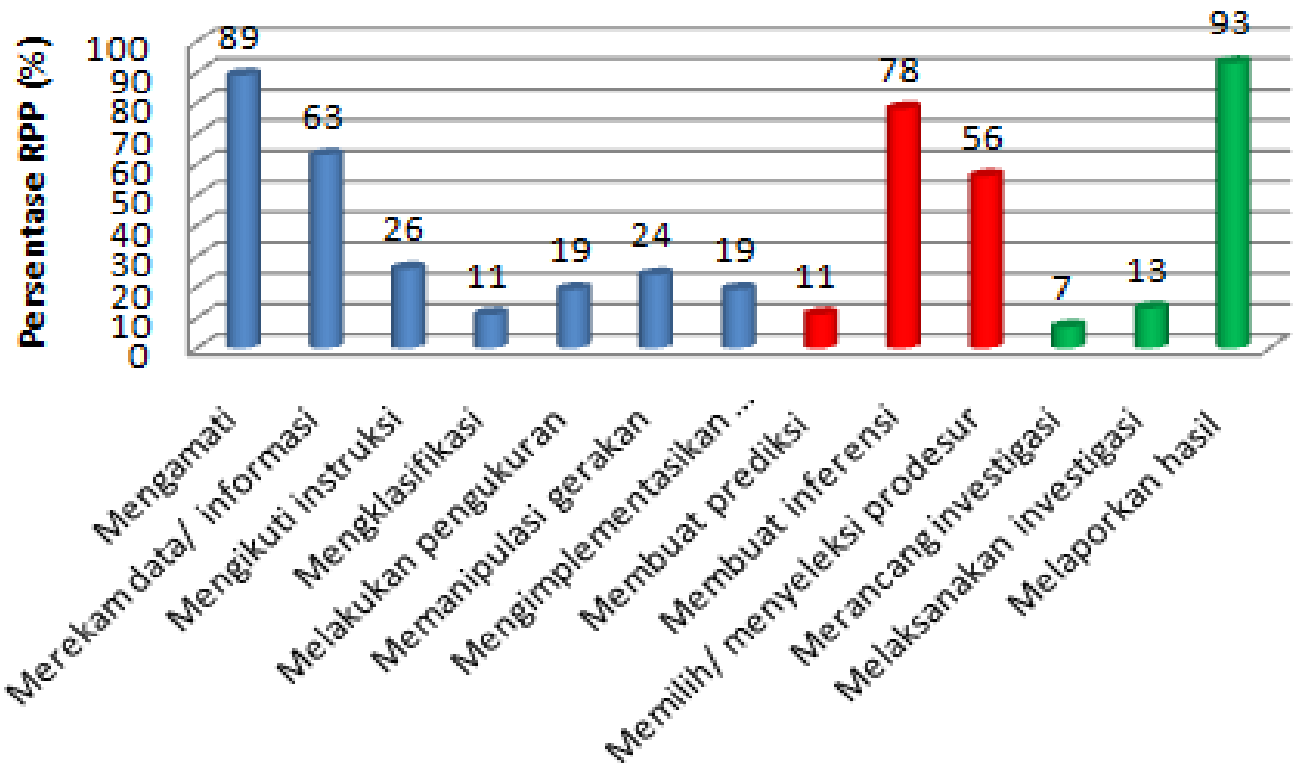

Gambar 4. Kegiatan pembelajaran berbasis KPS

Adapun tiga kegiatan KPS yang banyak dirumuskan dari yang paling tinggi ke rendah yaitu kegiatan melaporkan hasil investigasi (93\%), kegiatan mengamati (89 \%), dan menyimpulkan (78\%; Gambar 4)

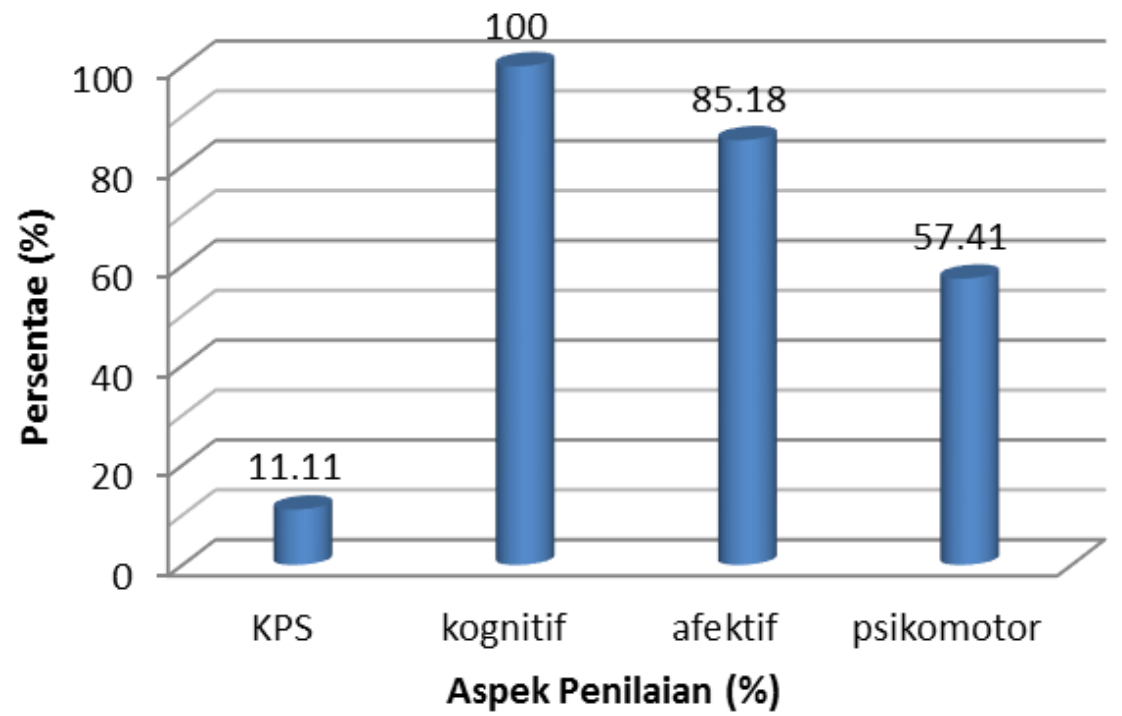

Gambar 5. Aspek penilaian yang dirumuskan oleh calon guru

Hasil penelitian juga menunjukkan bahwa mahasiswa calon guru telah mampu menggunakan kata kerja operasional yang bervariasi. Kata operasional yang paling banyak digunakan dalam rumusan tujuan pembelajaran adalah "menjelaskan" yaitu $81 \%$ sedangkan kata kerja operasional yang mencerminkan tujuan kegiatan pembelajaran berbasis KPS yaitu $<50 \%$ dengan rincian kata kerja 
operasional basic skills (2-33\%), process skills $(0 \%)$ dan investigative skills (2-50\%). Kata kerja operasional yang paling banyak

\section{Kemampuan}

\section{Mengorganisasikan Materi}

Kemampuan calon guru dalam mengorganisasikan materi yang sesuai dengan kompetensi dasar dan tujuan pembelajaran masih kurang baik. Materi pembelajaran yang disajikan dalam RPP oleh seluruh calon guru biologi $(100 \%)$ merupakan hasil penjabaran kompetensi dasar ke 3 yaitu aspek kognitif. Tidak ada satupun calon guru yang mencantumkan materi yang berkaitan dengan KPS padahal dalam tujuan pembelajaran terdapat rumusan tujuan pembelajaran berbasis KPS. Materi yang dipilih oleh sebagian besar calon guru biologi adalah materi biologi yang berupa fakta, konsep dan prinsipprinsip biologi.

\section{Kemampuan Memilih Sumber dan Media Belajar}

Hasil penelitian menunjukkan mahasiswa calon guru biologi sudah mampu memilih dan menggunakan sumber dan media belajar yang beragam.

Sumber belajar yang dipilih meliputi buku, internet, dan alam sekitar. Seluruh mahasiswa calon guru (100\%) memilih menggunakan buku sebagai sumber belajar. Sumber belajar lain yang dipilih yaitu internet (78\%) dan alam sekitar (28\%). Tidak ada mahasiswa yang memilih media cetak seperti surat kabar, dan majalah sebagai sumber belajar $(0 \%)$. Buku yang digunakan oleh calon guru adalah buku bse yang dapat di download secara gratis. Internet digunakan dalam pembelajaran untuk mencari berbagai informasi, gambar dan digunakan pada basic skills dan investigative skills secara berturutturut yaitu membedakan (33\%) dan mempresentasikan (50\%; Gambar 2) video/film yang berkaitan dengan materi. Alam sekitar digunakan oleh calon guru biologi sebagai tempat melakukan pengamatan atau observasi dan mencari bahan yang terkait dengan materi untuk dihadirkan dalam kelas seperti berbagai jenis makhluk hidup seperti jamur, tumbuhan dan hewan (Gambar 3)

Media pembelajaran yang digunakan oleh calon guru biologi cukup beragam mencakup media visual dan audio visual seperti power point, gambar, video atau film, charta, dan kartu soal. Sebagian besar calon guru biologi memanfaatkan teknologi dalam media pembelajaran seperti penggunaan laptop dan LCD. Media pembelajaran yang paling banyak digunakan dari yang terbesar hingga terkecil secara berturut-turut adalah powerpoint $(89 \%)$, gambar $(83 \%)$, video/film (26\%), charta (19\%) dan kartu soal (6\%).

\section{Kemampuan Menyusun \\ Langkah - Langkah Pembelajaran}

Hasil penelitian menunjukkan bahwa kemampuan guru dalam merencanakan langkah-langkah pembelajaran sudah cukup baik. Pada tahap pendahuluan, seluruh calon guru melakukan memotivasi peserta didik untuk belajar dan melakukan apersepsi dengan beragam cara seperti menujukkan sebuah gambar, video dan mengajukan pertanyaan untuk menggali pengetahuan awal peserta didik tentang materi tertentu. Pertanyaan yang diajukan berupa pertanyaan tentang materi yang 
telah dipelajari dan materi yang akan dipelajari. Namun demikian, masih terdapat kelemahan calon guru dalam mengajukan pertanyaan yaitu pertanyaan masih bersifat tertutup, belum muncul pertanyaan yang mengarahkan peserta didik untuk melakukan KPS. Misal : "Pertemuan lalu kita telah belajar sistem pencernaan. Apakah kalian tahu siapa yang menyalurkan sarisari makanan ke seluruh sel? apa yang kalian ketahui tentang jaringan tumbuhan? Apa yang kalian ketahui tentang pertumbuhan dan perkembangan?"

Pada kegiatan inti, kemampuan calon guru untuk merumuskan kegiatan pembelajaran berbasis KPS sudah cukup baik. Hal ini ditandai dengan dirumuskannya berbagai kegiatan pembelajaran yang mengarah kepada KPS. Pada basic skills sebanyak 11-89\%, process skills sebanyak 11-78 \%, dan investigative skills sebanyak 7-93\% (Gambar 4).

\section{Penilaian}

untuk $\begin{gathered}\text { Kemampuan calon guru } \\ \text { merancang penilaian }\end{gathered}$ pembelajaran berbasis KPS masih kurang baik. Calon guru biologi sudah melakukan penilaian secara lengkap meliputi penilaian aspek kognitif (100\%), aspek afektif $(85,18 \%)$ dan aspek psikomotor $(57,41 \%)$ tetapi konten penilaian tersebut belum sampai pada penilaian untuk aspek KPS.

Aspek kognitif dilakukan terhadap penguasaan konsep materi yang diajarkan dalam dengan menggunakan tes tertulis yaitu bentuk tes pilihan ganda, uraian dan benar-salah. Pada penilaian aspek afektif mahasiswa menggunakan teknik observasi. Adapun aspek afektif yang dinilai meliputi disiplin, kerjasama, jujur, peduli dan tanggungjawab. Mahasiswa telah melakukan penilaian psikomotor pada salah satu aspek KPS yaitu keterampilan melaporkan hasil investigasi (11,11\%; Gambar 5).

\section{PEMBAHASAN}

\section{Kemampuan \\ Tujuan Pembelajaran}

Hasil penelitian menunjukan bahwa kemampuan guru dalam merumuskan tujuan pembelajaran sudah baik meliputi kelengkapan cakupan (89\%), kesesuaian dengan kompetensi dasar (100\%) dan kesesuaiannya dengan pembelajaran berbasis KPS masih rendah. Hasil penelitian yang serupa pernah dilaporkan oleh Anggraeni (2009) yaitu tujuan pembelajaran yang dirumuskan oleh calon guru biologi pada kegiatan PLP (Praktek Latihan Profesi) sudah baik jika dilihat dari strukturnya. Tujuan pembelajaran yang dibuat lengkap, tidak meperlihatkan adanya penafsiran ganda dan menggunakan istilah jelas. Namun melihat dari konten masih sangat lemah dalam memuat kegiatan belajar yang sesuai dengan hakekat sains sebagai proses.

Calon guru juga sudah merumuskan tujuan pembelajaran menggunakan kata kerja operasional yang bervariasi. Kata operasional yang paling umum digunakan dalam rumusan tujuan pembelajaran adalah "menjelaskan" sebanyak $81 \%$. Hal ini menunjukkan bahwa calon guru masih berorientasi pada tujuan pembelajaran aspek kognitif daripada tujuan pembelajaran aspek keterampilan proses dan aspek lainnya. Hal ini belum sesuai dengan tuntutan kurikulum bahwa tujuan pembelajaran yang dirumuskan oleh 
guru berdasarkan $\mathrm{KD}$, dengan menggunakan kata kerja operasional yang dapat diamati dan diukur, yang mencakup tidak hanya pengetahuan tetapi sikap dan keterampilan (Kemendikbud, 2013). Keterampilan yang harus dikembangkan pada pembelajaran biologi adalah KPS. Guru biologi idelanya sudah seharusnya merumuskan tujuan pembelajaran dalam rangka melatihkan peserta didik dalam penggunaan dan pengembangan keterampilan proses dengan pemberian pengalaman belajar secara langsung sehingga diharapkan peserta didik memiliki keterampilan proses untuk menyelidiki alam sekitar, memecahkan masalah dan membuat keputusan secara mandiri (Subali \& Mariyam, 2013).

Kata kerja operasional yang mencerminkan tujuan kegiatan pembelajaran berbasis KPS masih kurang padahal seluruh calon guru biologi (100\%) menyatakan penting untuk membelajarkan sains/biologi disertai pengembangan keterampilan dalam melakukan proses ilmiah untuk memudahkan pemahaman ilmu biologi. Hal tersebut diduga karena sebagian besar calon guru belum memiliki pemahaman yang memadai tentang makna KPS sehingga mereka belum mampu merumuskan tujuan pembelajaran berbas is KPS. Hasil ini memberikan masukkan perbaikan pembelajaran pada mata kuliah yang memberikan bekal dasar dalam perancangan pembelajaran biologi.

\section{Materi}

Belum ada calon guru yang mencantumkan materi yang berkaitan dengan KPS padahal dalam tujuan pembelajaran terdapat rumusan tujuan pembelajaran berbasis KPS. Materi yang disusun berupa fakta, konsep dan teori sains, belum ada yang menyajikan materi perihal investigasi atau prosedur kerja ilmiah yang mengarahkan siswa untuk ber-inquiry seperti yang dituntut kurikulum.

Idealnya materi pembelajaran, memuat fakta, konsep, prinsip, dan prosedur yang relevan, dan ditulis dalam bentuk butir-butir sesuai dengan rumusan indikator ketercapaian kompetensi (Kemendikbud, 2013). Konten materi (topik dan subtopik) suatu mata pelajaran disusun dengan cara menurunkan dari keterampilan proses yang harus dikuasai peserta didik dari mulai pengamatan hingga penciptaan.

\section{Sumber dan Media pembelajaran}

Salah satu prinsip pembelajaran adalah belajar dengan menggunakan bermacam-macam sumber. Guru bukan lagi sebagai satu-satunya sumber belajar. Sumber belajar dapat berupa buku, media cetak dan elektronik, alam sekitar atau sumber belajar lain yang relevan. (Kemendikbud, 2013). Sumber belajar hendaknya disesuaikan dengan karakteristik peserta didik dan mata pelajaran. Mata pelajaran biologi sebagai bagian dari sains yang mempelajari tentang makhluk hidup dan alam sekitar semestinya bahan belajar yang bersumber dari alam sekitar lebih banyak digunakan dibanding dengan sumber belajar yang lain. Sumber pembelajaran yang dipilih calon guru biologi sudah cukup beragam namun sumber belajar dari alam sekitar dirancang guru hanya $28 \%$.

$$
\text { Calon guru biologi }
$$
menggunakan sumber dari alam 
sekitar seperti jamur, lumut, belalang. Namun penggunaannya masih terbatas sebagai contoh dalam pembelajaran pada saat menerangkan materi tertentu, belum sampai menggunakan sumber belajar tersebut sebagai bahan untuk melakukan kerja ilmiah atau penyelidikan lebih lanjut. Seluruh calon guru (100\%) menggunakan buku sebagai sumber belajar dan internet sebesar $78 \%$. Internet digunakan untuk mencari berbagai informasi terkait materi, mengunduh gambar, mengunduh video yang akan digunakan sebagai media pembelajaran. Kemudahan mendapatkan buku pelajaran seperti buku sekolah elektronik (BSE) dan mendapatkan buku pelajaran lainnya di perpustakaan, serta akses internet yang baik dilingkungan kampus diduga menjadi penyebab sumber buku dan internet paling banyak digunakan oleh calon guru.

Media pembelajaran, berupa alat bantu proses pembelajaran untuk menyampaikan materi pelajaran (Kemendikbud, 2013: 6). Powerpoint dan Lembar Kerja Siswa (LKS) paling banyak digunakan oleh calon guru sebagai media pembelajaran yaitu $89 \%$, calon guru cenderung kurang kreatif untuk membuat media pembelajaran dari bahan yang murah dan mudah didapat seperti charta dan kartu soal (6-19\%). Powerpoint digunakan calon guru untuk menjelaskan materi sudah cukup baik dengan dilengkapi gambar dan video terkait dengan materi. LKS yang disusun masih hanya memuat ringkasan materi dan daftar pertanyaan belum memuat sejumlah kerja ilmiah yang melibatkan KPS. Mahasiswa calon guru juga belum menggunakan berbagai bahan dan peralatan laboratorium yang tersedia sebagai media pada saat praktek mengajar. Terdapat kesan mahasiswa tidak mau repot mencari dan meminjam berbagai peralatan di laboratorium untuk praktek mengajar yang hanya diberi kesempatan selama 30 menit. Berdasarkan hal tersebut sangat diharapkan untuk meninjau kembali berbagai prosedur atau aturan pada kuliah mikroteaching demi perbaikan kualitas calon guru biologi.

\section{Kemampuan Menyusun Langkah - $\quad$ Langkah Pembelajaran}

Berdasarkan Standar Proses Pendidikan Dasar dan Menengah bahwa langkah-langkah pembelajaran dilakukan melalui tahapan pendahuluan, inti, dan penutup (Kemendikbud, 2013). Secara struktur calon guru sudah merumuskan langkah-langkah pembelajaran dengan baik meliputi kegiatan pendahulaun, kegiatan inti, dan kegiatan penutup. Langkahlangah pembelajaran berbasis KPS akan terlihat jelas pada tahap inti pembelajaran. Pada tahap inti idealnya harus muncul kegiatan KPS.

Kemampuan calon guru biologi dalam merencanakan langkahlangkah pembelajaran berbasis KPS masih kurang baik. Pada basic skills yaitu 11-89\%. Pada basic skills keterampilan mengamati muncul dengan persentase yang cukup tinggi (89 \%) tetapi masih kurang efektif. Kegiatan mengamati yang direncanakan sebagian besar hanya memaksimalkan satu atau dua indera saja yaitu indera penglihatan dan pendengaran. Objek yang diobservasi masih terbatas pada gambar dan video yang di download dari internet dan ditayangkan menggunakan media pembelajaran powerpoint. 
Pada pembelajaran berbasis KPS, keterampilan mengamati seharusnya sudah direncanakan guru dengan memaksimalkan kerja dari lima indera yaitu indera penglihatan, pendengaran, penciuman, pengecapan, dan indera peraba. Hal ini sangat penting karena keterampilan mengamati merupakan keterampilan dasar yang sangat penting bagi pengembangan KPS yang lain (Rezba et al., 2007). Kegiatan mengamati yang dirancang calon guru juga belum mengarahkan peserta didik untuk melakukan keterampilan lanjutan.

Pada process skills langkah pembelajaran yang paling banyak dirumuskan adalah menyimpulkan/membuat inferensi (78\%), tetapi keterampilan menyimpulkan yang muncul adalah menyimpulkan materi pembelajaran sebagai bagian dari kegiatan penutup. Keterampilan menginferensi belum sampai pada membuat inferensi untuk membedakan antara hasil observasi dengan rujukan, membuat generalisasi yang masuk akal berdasar hasil observasi, mengkombinasi observasi dan informasi yang diberikan untuk merumuskan hipotesis, membuat deduksi dari hipotesis, menggunakan hasil observasi untuk mengkonfirmasi atau membuktikan kesalahan/ menyangkut hipotesis dan memodifikasi hipotesis untuk mengakomodiasi observasi/ penelitian baru (Rezba et al., 2007).

$$
\text { Pada investigative skills, }
$$
keterampilan melaporkan hasil investigasi merupakan keterampilan yang paling banyak direncanakan oleh calon guru. Keterampilan melaporkan. Hasil penelitian/ investigasi dapat disajikan dalam bentuk gambar, tabel, grafik, peta, simbol, diagram, rumus matematika, dan demonstrasi secara visual menggunakan bahasa tulis maupun bahasa lisan sampai dengan menetapkan kebenaran hasil investigasi (Rezba, et al., 2007). Hasil penelitian menunjukkan bahwa seluruh calon guru merancang kegiatan melaporkan investigasi dengan menggunakan bahasa lisan melalui presentasi di depan kelas. Hal yang demikian dimungkinkan karena calon guru sudah terbiasa dalam melakukan presentasi oral pada perkuliahan sejak semester 1 sehingga calon guru menerapkan hal yang sama terhadap peserta didiknya. Belum ada calon guru yang merancang kegiatan aspek melaporkan hasil investigasi melalui gambar, grafik, diagram padahal calon guru sudah terbiasa pada dalam penyusunan laporan praktikum untuk menyajikan data dalam bentuk tabel maupun grafik.

Pada keterampilan merancang percobaan hasilnya paling rendah yaitu hanya $7 \%$ meskipun calon guru sudah terbiasa melakukan aktivitas-aktivitas yang merupakan aspek KPS dalam kegiatan praktikum. Kegiatan praktikum yang dilaksanakan selama ini lebih pada aktivitas untuk mengembangkan basic skills, process skills, dan sebagian sub aspek investigative skills. Aktivitas merancang percobaan sebagai sub aspek investigative skills yang menjadi bekal dasar merancang pembelajaran berbasis KPS masih belum dikembangkan secara maksimal. Calon guru masih terbatas mengikuti aktivitas - aktivitas yang sudah disusun dalam bentuk petunjuk praktikum sehingga calon guru belum terbiasa mengalami secara 
nyata

pengimplementasian

pembelajaran KPS secara utuh. Pengalaman ketika kuliahpun, mungkin belum mampu memberikan gambaran yang nyata tentang pengembangan KPS (kerja ilmiah) secara utuh.

\section{Penilaian}

Kemampuan calon guru untuk merancang penilaian pembelajaran berbasis KPS masih rendah. Aspek melaporkan hasil investigasi sebagai salah satu aspek investigative skills menjadi satu - satu nya aspek KPS yang dinilai oleh calon guru (11\%). Tes tertulis berupa tes pilihan ganda, tes uraian dan tes benar yang dirancang oleh seluruh calon guru $(100 \%)$ seluruhnya mengukur pengetahuan ranah kognitif. Belum ada satupun yang menyusun tes tertulis untuk mengukur penguasaan ranah kinerja/performance. Tes tertulis tidak hanya terbatas dapat digunakan untuk mengukur penguasaan berbasis pengetahuan ranah kognitif saja tetapi dapat juga digunakan untuk mengukur penguasaan pengetahuan untuk menampilkan kinerja/performans pada peserta didik (Subali, 2011). Tes tertulis dapat digunakan untuk mengukur keterampilan kinerja (performance skill) termasuk KPS karena di dalam penguasaan KPS terdapat aspek keterampilan kognitif (cognitive skills) yang menjadi melatarbelakangi penguasaan KPS pada peserta didik.

Merancang dan melaksanakan pembelajaran berbasis KPS seorang guru harus memahami dan memiliki keterampilan proses (process skills) yang akan mereka gunakan sebagai bekal dalam mengajar berbasis kerja ilmiah secara tepat di kelas mereka (Olson \& Horley, 2000). Secara keseluruhan kemampuan calon guru dalam merencanakan pembelajaran berbasis keterampilan proses sains (KPS) masih dalam kategori kurang dilihat dari berbagai aspek. Hal ini besar kemungkinan karena calon guru tersebut masih belum memahami dan memiliki penguasan KPS yang memadai sehingga mereka belum mampu merancang berbagai kerja ilmiah dalam pembelajaran berbasis KPS. Hal ini didukung oleh hasil angket yang menunjukkan bahwa sebagian besar calon guru $(>50 \%)$ menyatakan tidak memahami dan tidak mengetahui langkah-langkah pembelajaran biologi berbasis KPS. Terdapat sebanyak $69 \%$ mahasiswa juga menyatakan belum mampu merancang pembelajaran berbasis KPS.

Hasil penelitian yang serupa ditunjukkan pada hasil penelitian terhadap sekitar 120 calon guru fisika di sebuah perguruan tingggi swasta di Yogyakarta menunjukkan bahwa penguasaan KPS calon guru fisika masih dalam kategori kurang sampai dengan cukup. Hasil penelitian tersebut juga menunjukkan bahwa tidak ada perbedaan yang signifikan rata-rata penguasaan KPS antara calon guru pada berbagai tingkatan semester (Lindrawati \& Rohadi, 2015). Hasil penelitian lain juga menunjukkan bahwa rata-rata tingkat penguasaan KPS baik KPS basic skills, process skills dan integrative skills sebagai keterampilan esensial laboratorium pada mahasiswa calon guru IPA masih sangat rendah yaitu sebesar 35,50\% (Maknun et al., 2012).

Lemahnya kemampuan perancangan pembelajaran berbasis KPS juga diduga karena sedikitnya alokasi waktu yang disediakan untuk 
praktek mengajar (microteaching) yaitu hanya 30 menit untuk satu kali pertemuan padahal kegiatan pembelajaran di sekolah secara nyata rata-rata 2-3 jam pelajaran (90-120 menit) untuk satu kali pertemuan. Alokasi waktu yang sudah ditetapkan demikian berimplikasi pada rancangan pembelajaran atau RPP juga disusun hanya untuk pembelajaran selama 30 menit. Ketegasan alokasi waktu yang demikian tidak memungkinkan para calon guru untuk merancang waktu pembelajaran untuk kerja ilmiah yang melibatkan sejumlah KPS melainkan hanya berorientasi pada konten sains. Masalah yang serupa berpotensi berlanjut sampai dengan menjadi guru. Hal ini diperkuat dari penelitian yang pernah dilaporkan bahwa guru biologi di salah satu Sekolah Negeri di Kabupaten Bantul menyatakan alasan guru jarang melaksanakan pembelajaran berbasis KPS adalah sedikitnya waktu sedangkan materi yang harus disampaikan banyak. Guru lebih mementingkan semua materi selesai disampaikan untuk menghadapi UTS atau UAS (Risnani, 2015).

Secara

keseluruhan

pembelajaran berbasis KPS memerlukan perencanaan, pelaksanaan dan evaluasi yang cukup lama jika dibandingkan dengan pembelajaran standar (Donovan \& Bransford, 2005). Hal tersebut menjadi masukan untuk meninjau kembali dan mengembangkan kurikulum pada mata kuliah microteaching yang berpotensi pada tercapainya calon guru biologi yang profesional. Kegiatan mik roteaching idealnya di-setting dan diorganisasikan sedemikian rupa sehingga calon guru dapat tampil dan berupaya berperan seperti layaknya seorang guru di sekolah dari mulai tahap persiapan mengajar, pelaksanaan, dan evaluasi.

\section{KESIMPULAN}

Berdasarkan hasil penelitian diatas maka dapat disimpulkan bahwa kemampuan calon guru (preservice teacher) biologi dalam merencanakan pembelajaran berbas is keterampilan proses sains (science process skills) masih kurang baik. Diperlukan upaya perbaikan dalam pembelajaran yang diselenggrakan pada program studi pendidikan biologi sebagai LPTK untuk menciptakan calon guru biologi yang profesional.

\section{SARAN}

Berdasarkan kesimpulan diatas maka peneliti menyampaikan saran yaitu diperlukan penelitian lebih lanjut untuk mengukur penguasaan KPS calon guru biologi sebagai modal dasar bagi calon guru untuk membelajarka peserta didik dengan mengembangkan KPS.

\section{DAFTAR RUJUKAN}

Aktamis, H., \& Ergin, O. 2008. The effect of scientific Process Skills Education on Student Scientific Creativity, Science Attitude and Academic Achievements. Asia Pasific Forum on Science Learning and Teaching, (1): 1-21.

Anggraeni, S. 2009. Sudahkah Calon Guru Biologi Merencanakan Pembelajaran Biologi yang Sesuai dengan Hakekat Sains?. Makalah disajikan dalam Seminar Nasional Penelitian, Pendidikan dan Penerapan MIPA, Fakultas MIPA, Universitas Negeri Yogyakarta, Yogyakarta, 16 Mei 2009 
BNSP. (2006). Standar Isi untuk Satuan Pendidikan Dasar dan Menengah. Jakarta: BNSP

Bryce, T.G.K., McCall, J., MacGregor, J., Robertson, I.J., \& Weston, R.A.J. (1990). Techniques for Assesing Process Skill in Practice Science. Oxford: Heinemann Educational Books

Donovan M. S., \& Bransford J. D. 2005. How Students Learn: Science in the Classroom. Washington, D. C. The National Academy Press:

Harlent, W. 2001. The Assesment of Scientific Literacy in the OECD/PISA Project. Dalam H. Behrentet al., (Eds.), Research in science education-past, present, and future (pp. 49-60). New York, Boston, Dordrecht, London, Moscow: Kluwer Academic Publishers.

Lindrawati, B., Rohandi.

Keterampilan Proses Sains Calon Guru Fisika. Makalah disajikan dalam Pertemuan Ilmiah XXIX HFI Jateng \& DIY, Yogyakarta, 25 April 2015

Maknun, D. , Surtikanti, R.R.H.K., Subahar, T.S. 2012. Pemetaan Kterampilan Esensial Laboratorium dalam Kegiatan Praktikum Ekologi. Jurnal Pendidikan IPA Indonesia, 1, (1), 1-7

Peraturan Menteri Pendidikan Nasional Republik Indonesia Nomor 23 Tahun 2006 tentang Standar Kompetens Lulusan untuk Satuan Pendidikan Dasar dan Menengah. 2006. Jakarta: Kemendiknas

Peraturan Menteri Pendidikan dan Kebudayaan

Republik
Indonesia Nomor 65 Tahun 2013 tentang Standar Proses Pendidikan Dasar dan Menengah. 2013. Jakarta: Kemendikbud

Risnani, L.Y. 2015. Keefektifan Model Problem-Based Learning untuk Mengembangkan Berpikir Divergen dan Kreatif dalam Keterampilan Proses Sains (KPS) Peserta Didik Kelas X SMA N 2 Banguntapan, Bantul. Tesis tidak diterbitkan. Yogyakarta: Program Pascasarjana, Universitas Negeri Yogyakarta.

Schwartz, R.S., Lederman, N.G., \& Crawford, B.A. 2004. Developing view of nature of science in an authentic context: an explicit approach to bridging the gap between nature of science and science inquiry. Science Teacher Education, 610 - 645.

Subali, B., Mariyam, S. 2013. Pengembangan Kreativitas Keterampilan Proses Sains dalam Aspek Kehidupan Organisme pada Mata Pelajaran IPA SD. Cakrawala Pendidikan, XXXII, (3), 365381.

\section{Kreativitas Keterampilan} Proses Sains dalam Konteks Assesment for Learning. Cakrawala Pendidikan, 1, 130 $-144$.

Rezba, R.J., Sprague, C., McDonnough, J.T., \& Matkins, J.J. (2007). Learning and Assesing Science Process Skill. (5th ed.) Iowa: Kendall/ Hunt Publising Company.

Olson, H., Hosley, S. L. 2000. Inquiry and the National 
Science Education Standards:

A Guide for Teaching and

Learning. Washington, D. C. :

National Academy Press 